\title{
Strategic Corporate Social Responsibility and Value Creation among Large Firms
}

\author{
Lessons from the Spanish Experience
}

\author{
Bryan W. Husted and David B. Allen
}

Can corporate social responsibility (CSR) be a source of good and a wellspring of innovation, competitive advantage and value creation for the firm? Although CEOs and government leaders insist in public that CSR projects create value for the firm, privately they admit that they do not know if CSR pays off. To address this question and drawing on experience for the Spanish context, we test one of the few efforts to model how the strategic management of CSR may contribute to improving firm profitability (Burke and Logsdon, 1996). To do this, we examine the impact of three strategic CSR variables -.visibility, appropriability, and voluntarism - on value creation among large Spanish corporations. The conclusions from these findings suggest that managers need to understand how CSR is similar to and different from other traditional corporate market activities if they are to pursue value creation through CSR. We also suggest avenues for future research to explain how CSR may be integrated into firm processes to create resources (assets) and capabilities (routines) that may lead to competitive advantage and superior economic performance.

\section{Introduction}

Corporate social responsibility (CSR) has been defined in myriad ways. A common feature of many of the definitions is the proviso that firm activities can be considered as CSR when the firm under- takes "actions that appear to further some social good, beyond the interests of the firm and that which is required by law". ${ }^{1}$ However, this traditional definition, which clearly separated market from non-market (or social) activities, has given way to a new understanding driven by growing stakeholder pressure for greater CSR: firms are being asked to provide more and more social pro- grams designed to alleviate the world's ills as they are told that this will also lead to superior firm financial performance. ${ }^{2}$

However, managers like British Petroleum's Graham Baxter candidly worry that they just do not know whether CSR pays off. Baxter, in the wake of BP's failed "green strategy" and the subsequent firing of John Browne, cautions that while "Throughout BP's 100-year history, maintaining a positive working relationship with communities and broader society where we operate has been an important part of our success - the 'CSR Bubble' has become overinflated which, at worst, tries to create a parallel universe dangerously separate from business purpose and strategy."3

In our own work with U.S., Spanish, German and British multinationals in the pharmaceutical, banking and telecom industries, top management has frequently expressed skepticism of enthusiastic, high-profile academics like Michael Porter who claim that CSR can be both a source of good and a wellspring of innovation, competitive advantage and value creation for the firm. Man- agers rightly ask for clearer evidence of when and how nonmarket social activities can be converted into value-creating market activities. 
Unfortunately, academic studies have neither contributed significantly to our understanding of how CSR impacts on firm performance nor provided a compelling framework for the strategic management of CSR. After more than two decades of research on the relationship between CSR and firm financial performance, the results are mixed, at best: some studies show a positive relation- ship between the two; others, a negative relationship; and still others, no relationship. ${ }^{4}$ The reason for this failure is methodological: financial performance comes at the end of a long chain of mediating and independent variables. In other words, too many variables influence firm financial performance for us to isolate effectively the impact of CSR activities. ${ }^{5}$ Stated plainly, academics have been going about this the wrong way.

We agree with those managers who ask for a more instrumental, pragmatic approach to meet the laudable goal of satisfying legitimate stakeholder claims while at the same time creating competitive advantage and shareholder value. Accordingly, we propose re-configuring non-market social activities as social-market activities as a necessary first step in exploring how to manage CSR for value creation. This is consistent with the long-standing view in strategic management that a positive relationship between firm activities and value creation is more likely to be achieved when executives design projects that seek competitive advantage. In practical terms, strategic management of non- market social activities turns an expense into an investment with a measurable potential return.

However, we ought not to conclude blithely that managing CSR for profit is just like managing traditional market activities and that we can simply convert by decree non-market social activities into profitable goods and services. Salient and legitimate stakeholders may make demands on firms - e.g. General Motors must maintain pension commitments while competing against firms without such legacy commitments - such that some CSR activities provide opportunities for value creation while others do not. Evaluating firm CSR activities strengthening and expanding those that provide the potential for gain while diminishing the impact of those that put the firm at a disadvantage - is one of the key tasks of CSR management. Successful strategic management of CSR allows firms to take into account legitimate stakeholder claims, focusing and expanding work in those areas where competitive advantage can be created, while assigning appropriate allocation of resources to meet social needs. A secondary benefit of successful CSR strategy is that it encourages firms to seek additional ways in which social action also leads to profit.

The challenge, then, is how to model the strategic analysis of CSR. A promising approach was suggested in 1996 by Burke and Logsdon, ${ }^{6}$ who set out five strategic dimensions of CSR projects (visibility, appropriability, voluntarism, centrality, and proactivity) and posited that the strategic management of these dimensions in pursuit of competitive advantage would positively impact firm financial performance.

The framework presupposes that we understand how non-market social activities are different from market activities. We start from the standard innovation scenario in which the potential for creating value via non-market social activities is enhanced when competing with firms that do not treat CSR as a source of competitive advantage. However, the social aspect of CSR activities makes additional demands on firm behavior; not only must the company provide product or service attributes that create value, it must also provide a social good. In other words, strategic CSR opens a competitive space in which there are new opportunities but also additional demands to be met.

Two examples may help illustrate the challenge. In renewable energy, BP, the energy giant, was the first of the oil majors to go "green", and did so by announcing that this was a new strategy. Despite an initial round of praise, BP quickly came under pressure to meet raised stakeholder expectations. In fact, John Browne's recent resignation was due, in part, to his failure to deliver both on profits and going green. Another well-known example of the challenges of meeting competitive and social goals is Benetton. For more than a decade 
Benetton claimed a competitive space in which they offered progressive social consciousness as part of their brand positioning. This worked well until a controversial advertising campaign using death row inmates confronted resistance in the United States and Sears dropped the Benetton line of clothes. In response, Benetton abandoned its progressive social advertising and fired its long-term Advertising Director. In turn, the firm found itself attacked by its most loyal customers for being hypocrites. These customers did not accept the argument that the exigencies of business required the firm to make a change in market strategy. They demanded that Benetton fulfill both product and social issue customer demands. Since then, Benetton has been unable to reestablish its strategic position.

Our research objective is to examine which strategic dimensions firms

believe essential to creating value through CSR

With the dual nature of CSR in mind, we set out to consider how firms think about the strategic opportunities and demands of social action programs that link market objectives and non-market social objectives. To do so, we test Burke and Logsdon's framework via a survey of Spain's 500 largest firms. Our research objective is to examine which strategic dimensions firms believe essential to creating value through CSR. This knowledge, we argue, is necessary for the strategic management of CSR.

The Burke and Logsdon framework provides a useful starting point for this work. The framework was proposed as a practical instrument for helping managers develop CSR strategies that "pay off"; it was not a fully developed model with testable hypotheses. Accordingly, we have translated the framework into the resource-based view, and defined strategic CSR as the firm's ability to: 1) pro- vide a coherent focus to a portfolio of firm resources and assets (centrality); 2) anticipate competitors in acquiring strategic factors (proactivity); 3) build reputation advantage through customer knowledge of firm behavior (visibility); 4) ensure that the added value created goes to the firm (appropriability). ${ }^{7}$ Voluntarism, we should note, is missing from this description of strategic CSR, though it is a key variable in CSR value creation. We will return to this issue below in the theory section of the paper.

Given recent discussions of corporate citizenship, we should briefly discuss the relationship of strategic CSR to corporate citizenship. This task is made difficult by the fact that there is no consensus regarding the meaning of corporate citizenship. Some authors equate corporate citizenship with corporate social responsibility, while others seem to focus corporate citizenship specifically on the strategic aspects of CSR, much as we are doing in this article. Still others speak of citizenship as the responsibilities that corporations have with respect to their role as administrators in a system of citizenship. ${ }^{8}$ Thus, this paper on strategic CSR is more or less related to current conceptions of corporate citizenship, depending on the particular conception used. Since we test the Burke and Logsdon framework, we continue their usage and employ the term "strategic CSR", leaving aside debates about the meaning and scope of corporate citizenship.

The remainder of the paper is organized as follows: we first set out in greater detail how CSR projects may help firms create value and develop hypotheses for three of the five strategic dimensions that seem to have an impact. We then discuss the research methodology, data analysis and results. In the discussion and conclusions section, we indicate the contribution of the individual strategic dimensions to value creation and implications of the results for firm strategy, management practice and public policy. We conclude with suggestions for future research.

\section{Theory}

In the strategic management literature, it is generally agreed that competitive advantage 
requires, in addition to superior firm resources and capabilities, a fit between the external environment and the strategic action of firms. Strategic action, in turn, it is argued, is driven by top management's values, including commitment to both profit and social responsibility. ${ }^{9}$

Strategic management researchers have asserted that CSR can provide

opportunities for innovation

However, asserting that values are the basis for management principles and action does not mean that increased social responsibility is the best or easiest route to value creation and profitability. The first step in finding this route, as we indicated earlier, is to move beyond the simplistic approach that CSR is inherently profitable. Strategic management theory has consistently argued that the key to success resides in creating competitive advantage which, skillfully managed, results in value creation. Value is created when consumers are willing to pay a premium for the firm's products and services based on its involvement in and position with respect to specific social issues. Value creation occurs when firm resources are combined in new ways so as to increase the potential productivity of those resources. ${ }^{10}$ Thus, value creation is necessarily about innovation. Strategic management researchers have asserted that CSR can provide opportunities for innovation. ${ }^{11}$

Yet, just as all market-based projects do not create value, not all CSR projects will create value for the firm. ${ }^{12}$ Many CSR projects, in fact, increase costs, and although they may be positively evaluated by different stakeholder groups, stockholders may see the value of their shares diminished. For ex- ample, The Body Shop is frequently cited as a classic case of joining products and CSR. Unfortunately, The Body Shop also found that CSR could increase costs significantly. Intent on maintaining its commitment to a broad range of local suppliers, manufacturing costs skyrocketed, and as other firms copied its products and outsourced to Asia, The Body Shop's profits plummeted. Finally, Anita Roddick was forced to bring in management willing to put profit before CSR.

In effect, the challenge CSR faces is an elegant inversion of the old conundrum of social cost. 13

Rather than worrying about how to compensate others for harm done in the process of creating value for our business, we need to figure out how social benefit creates value rather than cost for business firms.

Explaining, then, how social action creates value remains a key stumbling block to a theory of the firm that incorporates CSR. Our approach to this problem is to treat CSR as a strategic value creator. In our research, we ask managers to detail their understanding of their firms' analysis of the social issues (stakeholder) environment and of how these firms create value through CSR projects. Specifically, the Burke and Logsdon model sets out, as we outlined above, five strategic dimensions of CSR projects that may affect the ability to create value: visibility, appropriability, voluntarism, centrality, and proactivity. In this paper, we examine the hypothesis that firms with social (CSR) projects designed and managed to create greater visibility, appropriability, and voluntarism are more likely to undertake advantageous reconfigurations of resources and capabilities and hence create greater value for the firm. It is important to note, moreover, that a firm need not successfully apply all the variables in order to create value; one of the key objectives of the research is to deter- mine which of the variables are currently being employed by firms.

In Table 1, we provide a comparison of the strategic CSR approach proposed by Burke and Logsdon with traditional strategy and traditional CSR based on the original five dimensions of their model.

Below, we examine three of the five dimensions in more detail and set out a hypothesis of the relationship of each dimension to value creation. We limit our discussion to these three dimensions given that our preliminary research indicates that centrality and proactivity do not affect value creation in the Spanish context. ${ }^{14}$ 
Visibility is the extent to which social activities may be observed by the firm's stakeholders. Visible CSR activities may affect the reputation of the firm positively. Research has demonstrated that a good corporate reputation has a significant potential for value creation and is difficult to replicate. ${ }^{15}$ Reputation is a key competitive advantage in markets where product differentiation is difficult, attracting superior workers and providing leverage for managing stakeholders. ${ }^{16}$ However, the decision to leverage CSR visibility is not comfortable for all firms. Neopets, a California based

Table 1. A Comparison of Traditional CSR, Strategic CSR, and Traditional Strategy

\begin{tabular}{|c|c|c|c|}
\hline \multirow{2}{*}{$\begin{array}{l}\text { Strategic } \\
\text { Dimension } \\
\text { s }\end{array}$} & \multicolumn{3}{|c|}{ Different Approaches to CSR and Strategy } \\
\hline & Traditional CSR & Traditional Strategy & Strategic CSR \\
\hline Visibility & $\begin{array}{l}\text { Irrelevant: Doing good is its } \\
\text { own reward e and is } \\
\text { profitable in the long run. }\end{array}$ & $\begin{array}{l}\text { Build customer awareness } \\
\text { of product and brand. }\end{array}$ & $\begin{array}{l}\text { Building customer and } \\
\text { stakeholder awareness } \\
\text { of product with CSR } \\
\text { value added. }\end{array}$ \\
\hline Appropriability & $\begin{array}{l}\text { Irrelevant: Doing good is } \\
\text { its own reward } e \text { and } \\
\text { profitable in the long run. }\end{array}$ & $\begin{array}{l}\text { Manage supplier, } \\
\text { customer, and competitor } \\
\text { relations to capture value }\end{array}$ & $\begin{array}{l}\text { Manage stakeholder } \\
\text { relations to capture value } \\
\text { added for the firm. }\end{array}$ \\
\hline Voluntarism & $\begin{array}{l}\text { Participate in social action } \\
\text { beyond that demanded by } \\
\text { the firm's interests and the } \\
\text { law. }\end{array}$ & $\begin{array}{l}\text { added for firm. Firm } \\
\text { innovation based on ability } \\
\text { to learn: non } e \\
\text { deterministic behavior. }\end{array}$ & $\begin{array}{l}\text { Participate in social } \\
\text { action beyond that } \\
\text { demanded by law. } \\
\text { Create value via product/ }\end{array}$ \\
\hline Centrality & $\begin{array}{l}\text { Irrelevant: Doing good is } \\
\text { tied to social need and not } \\
\text { to core business mission. }\end{array}$ & $\begin{array}{l}\text { Create value via product/ } \\
\text { service innovation. }\end{array}$ & $\begin{array}{l}\text { service innovation linked } \\
\text { to social issues. }\end{array}$ \\
\hline Proactivity & $\begin{array}{l}\text { Anticipate changes in } \\
\text { social issues. }\end{array}$ & First-mover advantage. & $\begin{array}{l}\text { Anticipate changes in } \\
\text { social issues that present } \\
\text { market opportunities. }\end{array}$ \\
\hline
\end{tabular}


company that has developed an on-line virtual pet community with over 25 million members and one of the world's most visited websites, is regularly involved in a broad range of CSR activities; however, they deliberately do not publicize these activities and consider CSR activities to be part of "giving something back to the community" and "something you do, but don't publicize". Top management at Neopets would consider it simply inappropriate to look to make money out of doing the right thing. 17

Taking precisely the opposite approach, Telefonica, the Spanish telephone multinational, has incorporated CSR directly in value creation as part of its widely publicized reputation strategy. In 2002, Telefonica's President, César Alierta, decided to integrate CSR into the firm's corporate strategy, establishing a fully staffed Corporate Reputation Department charged with actively seeking publicity for CSR activities. The firm's global reputation project set out CSR objectives throughout the world, and established IT systems to measure CSR media impact and reputation gains in the belief that reputation translates into increased sales. ${ }^{18}$ Telefonica's top management is convinced that greater visibility for CSR projects enhances firm reputation and customers will be willing to pay a price premium for the firm's products or services. An additional expected benefit to CSR visibility is consolidation of Telefonica's position with regulators, the investment community and other non-market stakeholders. Although the analysis of value creation is more complex than in traditional market activities, CSR projects can be a source of competitive advantage.

Hypothesis 1 . The greater the visibility of a firm's CSR projects, the greater the potential for value creation through such projects.

One of the kinds of appropriability that is especially relevant to value

creation is product differentiation

In the context of CSR, appropriability may be defined as the ability of the firm to extract economic benefits from a social project. One of the kinds of appropriability that is especially relevant to value creation is product differentiation. Such product differentiation can be created by endow- ing a product with CSR attributes (product innovation) or developing the product through CSR- consistent processes (process innovation). In either case, the firm creates a new market for such CSR products with consumers who are willing to pay a price premium for products with CSR attributes.

For example, Patagonia, the California-based outdoor and sportswear manufacturer, represents a firm that has created a new market for its CSR products. Patagonia sets out to be an environmen- tally friendly supplier of outdoor gear, and began manufacturing its garments with recycled poly- ethylene terephthalate (PET). From the beginning, Patagonia's marketing has focused on the environmental-friendly dimensions of its products e e.g., organic cotton $\mathbf{e}$ and their innovative improvements (mostly patented and trademarked) motivated by the drive to be more environmentally friendly. Patagonia's clothes sell at about $50 \%$ or more than competitors such as LL Bean and Eddie Bauer. ${ }^{19}$ The firm has maintained its competitive advantage by remaining focused on the appropriability of its social projects by both creating CSR products and pricing them above substitute offerings.

In Spain, Bosques Naturales, a forestry development company, and MRW, a package delivery company, have focused their corporate strategies around the appropriability of CSR strategies. It is vital to keep in mind that appropriation of rents is, in effect, a measure of the firm's ability to make sure that the potential value created actually goes to the firm and not to others in the market environment. In the cases of Bosques Naturales and MRW, appropriability has been linked carefully to strategic elements implicated directly in value creation, as we explain below in our discussion of voluntarism. 
Hypothesis 2. The greater the appropriability of a firm's CSR projects, the greater the potential for value creation through such projects.

Voluntarism refers to the sense in which social activities are undertaken freely, because firms want to, rather than as a result of legal constraints or fiscal incentives. In discussing strategic initiatives, this is usually not a consideration; strategy theory assumes that the active pursuit of competitive advantage is voluntary. Accordingly, in our introduction when we described strategic CSR in terms of the resource-based view, we omitted voluntarism. Thus, the inclusion of voluntarism as an in- dependent variable in strategic CSR requires some additional explanation.

Voluntarism recognizes that there is something fundamentally different between market activities and nonmarket CSR projects

Voluntarism recognizes that there is something fundamentally different between market activities and non-market CSR projects. Business firms are designed to take advantage of market opportunities; for this reason, until recently, strategic management theory largely ignored non-market CSR projects in value creation beyond recognizing the importance of values and corporate culture in developing internal consistency and employee commitment. 20 However, the inclusion of CSR projects in relation to value creation opens strategic opportunities once we recognize that all firm activities may be a source of value creation.

Within the CSR literature, the opposite has normally been assumed $\mathbf{e}$ firms do not, and should not, pursue competitive advantage via CSR. Burke and Logsdon, in their attempt to provide man- agers with a practical approach to CSR and value creation, were pioneers in recognizing that, in an environment where other firms do not seek competitive advantage via CSR activities, the decision to voluntarily go beyond legally mandated social action can become a source of value creation. In the Burke and Logsdon model, CSR voluntarism becomes economically rational $\mathbf{e}$ a source of competitive advantage $\boldsymbol{e}$ when it is linked to the other strategic dimensions, hence allowing firms to create unique resources and capabilities valued by customers and difficult to imitate. ${ }^{21}$ At a time when academic research and the popular press were focused on making sweeping claims that CSR was good for profit, the Burke and Logsdon model was one of the few attempts to say how that could be done.

Once again, as a practical example, MRW is exceptionally useful. In the package transportation business, competition has largely focused on reducing the cost of fast and efficient delivery. MRW's strategy has consisted in treating fast and efficient low-cost delivery as a common denominator for those competitors who will survive, while developing an array of CSR product attributes for multiple customer groups. For example, MRW offers free package delivery once a month to the families of Spanish students overseas, to the handicapped, to the elderly in residences over 50 kilometers away from family, and so on. MRW sees its CSR program as a broad range of voluntary behaviors that it expects other firms not to match. Many of these beneficiaries become MRW customers; still other customers recognize MRW's ability to provide specialized services to meet specific customer segments.

However, the original argument of Burke and Logsdon with respect to voluntarism does not settle the matter. Work by Michael Porter and his colleagues suggests that legal constraints,

such as environmental regulation, can actually spur innovation. ${ }^{22}$ In other words, involuntary constraints can provide firms with the incentive to innovate, especially with respect to social and environmental problems. Thus, the relationship of voluntarism to value creation is uncertain. There are reasons to believe that it may foster value creation; however, there are also good reasons to believe that con- strained action may also help to create value. The impact of this variable may be either positive or negative and may in fact depend upon specific 
contexts within which firms operate. Thus, in order to accommodate either possibility, we propose:

Hypothesis 3. The voluntariness of CSR projects may either increase or decrease the potential for value creation through such projects.

Methods

\section{Data collection}

After some deliberation, we decided on asking for perceptual data from the top management individual responsible for CSR activity at the firm. Previous studies have principally relied on aggregate measures of financial performance that have provided inconclusive evidence for a CSR-financial performance linkage. Accordingly, we have focused on the firm project level in order to discover how value is created by strategic CSR.

We began this paper by stating that "managers don't know if CSR pays off". As we argued earlier, there is no consensus that CSR can, or even should, be managed for profit, just as other business processes are managed for profit. As a result, well-intentioned CSR researchers have sought to find a way to demonstrate CSR profitability without having to claim that management takes strategic action to create value. This research agenda did not succeed because it could not specify how competitive advantage and value are created. In order to do so, we have chosen to focus on top management, precisely because they are in the best position to explain the strategic intent of their portfolio of social action projects.

It is crucial to test the extent to which top management seeks competitive advantage and value creation via CSR in an uncertain

environment

In sum, given that most managers do not know whether CSR pays off, we consider it crucial to test the extent to which top management seeks competitive advantage and value creation via CSR in an uncertain environment. Such a test would be unnecessary if we were to ask, for example, about marketing strategy; it is hard to imagine the Executive Vice-President for Marketing of a large Spanish company admitting that the firm does not consider marketing a source of competitive advantage and that he is not sure how to create competitive advantage via marketing.

Working from managerial intent requires accepting certain trade-offs. By shifting to a more micro focus, we also leave behind more objective indicators of value creation. On the project level, one would almost have to engage in a cost-benefit analysis of each project in order to determine the value created. Firms do not yet engage in such fine-grained evaluation of their CSR projects. Given the current state of the art of CSR management and reporting, we decided that we needed to rely on the perceptions of the managers responsible for CSR regarding the strategic goals of CSR projects. Such perceptions of firm benefits and of the quality of stakeholder relations may be biased. In response to this issue, we have applied the necessary methods to control for possible bias.

Support for using perceptual managerial data rather than external stakeholders and other secondary databases comes from the theoretical literature and from practical research issues. There is considerable theoretical support for using perceptual data. ${ }^{23}$ If, in fact, managerial decision- making is driven by the beliefs of top management, it makes sense to ask how management perceive the environment and the extent to which they believe they are responding to CSR challenges in a strategic fashion. 
On a practical level, external databases of CSR and reputation surveys in Spain principally ask top management which firms they most admire. The resultant reputation and CSR rankings overweight firm size and profitability. External stakeholder groups, in particular NGOs, rarely deal with a large cross-section of firms and either speak favourably of partners with whom they collaborate or negatively of large firms that have conflicts with specific stakeholders. However, the managers we questioned are well aware of their firm's PR and marketing programs for CSR and corporate reputation. These managers from the kinds of large companies we surveyed are well aware of their rankings in the CSR and reputation surveys. Our use of perceptual measures serves the purpose of telling us the extent to which managers seek to communicate with stakeholders and convince them that the firm is socially responsible.

In short, while external databases and stakeholders may provide insight into firm behaviour regarding social issues, these sources do not measure the strategic import of stakeholders for firms nor how firms seek to create value through CSR. This can only be done by asking top management itself. We are aware, nonetheless, of the limitations of our data and perceptual measures; our results must be handled with caution, inviting further research, awaiting the moment when more fine- grained, objective data will be available.

A survey instrument was developed to measure the basic constructs of value creation, visibility, appropriability, and voluntarism. We include the items used to measure these constructs in Appendix 1. Each of these items was measured using a five-point Likert scale. The face validity of the instrument was determined by a detailed examination of the instrument by ten academics and business people who reviewed the instrument items for clarity. A small pilot study was then carried out and the preliminary results found the measures to be robust.

In addition to the variables of theoretical interest, CSR researchers have emphasized the need to control for firm size, risk, and industry. Firm size was measured by the number of employees. Industries were classified according to the Spanish system of industrial classification. We used a dummy variable for industry. We also included the debt ratio (debt/assets) as our measure of risk.

Firms were selected from the Dicodi database of Spanish firms, published by Equifax Iberica. It consists of a total of almost 50,000 firms throughout the country. Data collection was carried out from April to September 2002. We sent the survey to the 500 largest firms in the database as measured by number of employees. We focused on the largest firms because they were more likely to have engaged in CSR activity. We telephoned all the firms to identify who in the top management team would be the best person to respond to the survey. 110 surveys were completed either after the initial mailing or as a result of the follow-up. This represents a response rate of $22.0 \%$. As a further control, in approximately half of the cases, we spoke directly to the individual filling out the survey to confirm that they understood the purpose of the survey and would be able to provide accurate data. All the surveys were reviewed as well by two researchers for inconsistencies in the data, response patterns and outliers.

Sixty-three firms were in service industries and forty-seven were in manufacturing. The firms came from such diverse industries as mining and natural resources (9), heavy manufacturing and chemicals (19), light manufacturing and consumer products (14), energy and construction (5), commerce (14), financial services, telecommunications, and transportation (32), and other services (17). The firms had an average of 4,260 employees, ranging from 277 to 37,510 employees.

\section{Data analysis}

The hypotheses were analyzed using ordinary least squares (OLS) regression analysis. The dependent variable was value creation. The independent variables were visibility, 
appropriability, and voluntarism. Since the dependent variable is continuous and the data are cross-sectional, such a model appeared appropriate. Following standard procedure in CSR research, we controlled for company size, risk, and industry.

Table 2 shows the correlation matrix for the variables. The correlation matrix suggests a significant correlation between voluntarism and visibility. These significant correlations raise the possibility of multicollinearity, which violates one of the assumptions for OLS. Multicollinearity occurs when any independent variable is highly correlated with any of the other independent variables. The effect of multicollinearity is to depress the significance of the affected variables. Nevertheless, the severity of multicollinearity needs to be tested more thoroughly.

We undertook tests to demonstrate the reliability and validity of the constructs, and tests to detect problems of common-method variance, non-response bias, heteroskedasticity, and multicollinearity. The results of these tests demonstrated the robustness of the variables and that the assumptions for OLS regression were not violated. The results of these tests appear in Appendix 2.

\section{Results}

A hierarchical regression analysis was conducted. In all of the models we included the control variables. Following the resource-based view definition set out in the introduction, in model 1 , we introduced the control variables and appropriability. In model 2, we added visibility. Finally, voluntarism was introduced in model 3. The results appear in Table 3. The coefficients of the variables indicate the impact of each variable on value creation. For example, in model 5 , the coefficient of 0.22 for appropriability means that a one-unit increase in appropriability increases value creation by 0.22 units.

Generally speaking the control variables were not significant or only marginally significant. The sole exception was risk measured as debt in model 3, which was significant at the 0.05 level. The heavy manufacturing and chemical firms did appear to be marginally significant. These firms typically have had environmental problems, which may explain why they have a greater, negative impact on value creation than other industries. In terms of the independent variables, appropriability, visibility, and voluntarism were at least significant at the 0.05 level. However, voluntarism had the opposite sign than that expected by Burke and Logsdon, in support of the Porter hypothesis. The addition of appropriability, visibility, and voluntarism all increased the explanatory power of the model significantly as indicated by the change in $\mathrm{R}^{2}$ and the F-statistic.

\section{Table 2. Correlations}

\begin{tabular}{|c|c|c|c|c|}
\hline Variable & 1 & 2 & 3 & 4 \\
\hline 1. Value creation & & & & \\
\hline 2. Appropriability & $0.45^{\star \star}$ & & & \\
\hline 3. Visibility & $0.42^{* \star}$ & $0.28^{\star *}$ & & \\
\hline 4. Voluntarism & $-0.56^{\star \star}$ & $-0.34^{\star \star}$ & $0.26^{\star}$ & \\
\hline 5. Debt & -0.02 & -0.05 & 0.02 & -0.16 \\
\hline 6. Firm size & -0.09 & -0.01 & -0.11 & 0.09 \\
\hline $\begin{array}{l}\text { 7. Agriculture and } \\
\text { Mining }\end{array}$ & -0.04 & 0.05 & -0.12 & -0.08 \\
\hline $\begin{array}{l}\text { 8. Heavy } \\
\text { Manufacturing, } \\
\text { Chemicals }\end{array}$ & -0.06 & 0.17 & 0.02 & 0.06 \\
\hline $\begin{array}{l}\text { 9. Equipment, } \\
\text { Consumer } \\
\text { Products }\end{array}$ & -0.10 & $-0.22^{\star \star}$ & 0.07 & 0.08 \\
\hline $\begin{array}{l}\text { 10. Energy, Water, } \\
\text { Construction }\end{array}$ & -0.03 & -0.09 & $-0.27^{\star \star}$ & 0.10 \\
\hline 11. Commerce & 0.14 & 0.08 & 0.03 & 0.01 \\
\hline
\end{tabular}




\begin{tabular}{lllll} 
12. Financial Services & -0.03 & -0.11 & 0.01 & -0.10 \\
$\begin{array}{l}\text { and } \\
\text { Telecommunicatio }\end{array}$ & & & & \\
ns & & & & \\
13. Other Services & 0.12 & 0.11 & 0.08 & -0.02 \\
\hline
\end{tabular}

${ }^{\star *} p<0.01 ;{ }^{\star} p<0.05$

Table 3. Results of O.L.S. Regression Analysis ${ }^{1}$

\begin{tabular}{llll}
\hline \multicolumn{1}{c}{ Variables } & Model 1 & Model 2 & Model 3 \\
\hline (Constant) & $.209(.946)$ & $.222(.894)$ & $.762(.792)$ \\
Debt & $-.694(.646)$ & $-.648(.610)$ & $-1.192^{\star}(.547)$ \\
Firm Size & $-.132(.089)$ & $-.102(.085)$ & $-.073(.075)$ \\
Agriculture and Mining & $-.660(.476)$ & $-.444(.454)$ & $-.652(.401)$ \\
Heavy Manufacturing, Chemicals & $-.680 \dagger(.367)$ & $-.607 \dagger(.348)$ & $-.561 \dagger(.371)$ \\
Equipment, Consumer Products & $-.140(.334)$ & $-.239(.317)$ & $-.167(.279)$ \\
Energy, Water, Construction & $.064(.570)$ & $.468(.552)$ & $.557(.485)$ \\
Commerce & $.077(.354)$ & $.108(.335)$ & $.200(.294)$ \\
Other Services & $.006(.323)$ & $-.059(.305)$ & $.032(.269)$ \\
Appropriability & $.427^{\star \star *}(.095)$ & $.342^{\star \star \star}(.094)$ & $.222^{\star}(.086)$ \\
Visibility & & $.333^{\star \star \star}(.102)$ & $.243^{\star \star}(.091)$ \\
Voluntariness & & & $-.445^{\star \star \star}(.090)$ \\
$\mathrm{R}^{2}$ & .250 & .340 & .498 \\
Change in $\mathrm{R}^{2}$ & .250 & .090 & .158 \\
Change in F & $2.967^{\star \star}$ & $10.713^{\star \star}$ & $24.527^{\star \star \star}$ \\
\hline
\end{tabular}

$\dagger p<0.10 ;{ }^{*} p<0.05 ; * \star p<0.01 ; * \star p<.001$.

1 Coefficients (standard errors appear in parentheses).

\section{Discussion}

As is the case in many prescriptive strategy models, Burke and Logsdon set out five independent variables which ideally would all positively align to create value. However, only three of the five variables (visibility, appropriability, and voluntarism) are perceived by Spanish firms to be related to value creation. In the following discussion, we explain why we believe this to be so.

Visibility is clearly understood to be related to value creation. To the extent that consumers and other stakeholders are perceived to observe CSR activity, they are able to reward firms for their participation. A greater presence of CSR programs in the media and a favorable firm image appear to have a positive impact on the ability of the firm to generate value through increased customer loyalty, the attraction of new customers, and the development of new products and markets. The visibility results are clear and direct. It is likely that this is a reflection of the perception that many firms hold regarding the contribution of CSR to firm reputation.

Firms perceive that designing CSR projects with the intent to generate

benefits is necessary for value creation

Appropriability also significantly affects the creation of value through CSR projects. In other words, firms perceive that designing CSR projects with the intent to generate benefits is necessary for value creation. Thus, to the extent that large Spanish firms undertake CSR, 
they are aware that they should design them in ways that create economic benefits; they recognize that since markets are competitive, firms could benefit from differentiating products with CSR attributes. Once again, we should keep in mind that if we were considering market product and service activities, we would expect ALL firms to assign importance to designing projects to create value.

As predicted, voluntarism is an essential element for the creation of value, but not in the direction hypothesized by Burke and Logsdon. They thought that greater voluntarism would lead to greater creation of value from strategic CSR projects. On the contrary, and in accordance with the Porter hypothesis, among large Spanish firms, value creation is associated with constraints such as legal requirements, industry practice, and fiscal incentives. These results suggest that large Spanish firms are more likely to create value from CSR projects when such projects are perceived to arise as the result of industry, fiscal, and regulatory constraints.

The results indicate a panorama in which firms want to benefit from CSR and understand its strategic importance, but are in an early competitive phase in which first-movers believe that simply being in the market with a CSR product is an achievement in itself. At the same time, there is a prevailing social climate in which it is institutionally expected that firms will actively talk about how important CSR is to firm performance. Telefonica, for example, has incorporated CSR within its corporate reputation area with the specific goal of encouraging the inclusion of CSR in company-wide strategic planning across its divisions. At the same time, Telefonica executives have shown striking honesty in recognizing that business-unit managers too often confuse CSR with regulation and find it difficult to see the connection between real business opportunities and CSR. Within Spain, many see CSR as necessary to reputation building in a market where product differentiation is nearly impossible. At the same time, in Latin America, regulators have required Telefonica and its affiliates to provide services that are not profitable, particularly in rural areas, so that CSR may be assumed as a necessary cost of being in certain markets. Nonetheless, rural farmers in developing countries have become a profitable segment for mobile telephone operators.

It is likely that this complex and contradictory competitive environment is reflected in the positive results for visibility (closely related to the positive reputation effects associated with $\mathrm{CSR}$ ) and appropriability (directly related to managing stakeholders for value creation) - as well as the importance given to merely meeting non-voluntary requirements.

There is significant lag in implementing strategic management of

social action activities that go beyond legal requirements

The overall picture painted by these results seems to indicate that, despite the dependence on non-voluntary CSR activities among large Spanish firms for creating value through CSR, firms nonetheless perceive that CSR projects will create value when they are constrained to undertake such projects and develop such projects in ways that are designed to generate economic benefit, particularly when CSR projects are highly visible to the public. However, although Spanish firms appear to understand some of the strategy principles involved in CSR value creation, there is significant lag in implementing strategic management of social action activities that go beyond legal requirements. One possible reason is that the complexities of managing strategic CSR $\mathbf{e}$ the dual demands of tangible competitive advantage and social action - discourage firms.

Conclusions: CSR, public policy, future directions

An understanding of the conditions under which CSR may create value is crucial to developing a theory of strategic CSR. All firm activities may add value in the moment that they reduce costs, create product differentiation, or move customers to buy from one firm rather than another. CSR is an opportunity to re-configure the competitive landscape as well as to develop distinctive and dynamic resources and capabilities. 
CSR also provides a possibility for innovation. However, it is not a given that CSR innovation will either produce competitive advantage or value creation. To understand how this may be the case, we have operationalized the strategic management of CSR and CSR value creation and developed hypotheses about how CSR can contribute to improved firm performance.

Though Spanish firms state that they understand the potential for CSR to contribute to value creation, they do not yet know how to re-orient non-market CSR projects toward value creation. In other words, there is a declaration of intentions that has yet to be met by action. This is not just an issue in Spain, however. Civil society organizations such as Business for Social Responsibility and The Global Compact network, continually express concern that firms know the right things to say, do some of the right things, but doubt that firms truly believe that CSR represents a business opportunity.

We sorely need proof that CSR can be managed for value creation

In fact, if firms truly were convinced, the recent attack on CSR in The Economist might not have produced such an uproar and outpouring of protest. ${ }^{24}$ We sorely need proof that CSR can be man- aged for value creation. Anomalous situations, such as the Spanish case, in which large firms perceive benefits from involuntary constraints such as governmental regulation, tax incentives, and industry pressure, only raise more questions. One possible explanation is that large Spanish firms are less CSR sophisticated than the U.S. companies that served as the context for the original work by Burke and Logsdon. On the other hand, as we argued above, it may be that Spanish firms perceive a potential danger to value creation in doing good or believe that CSR is too difficult to man- age as a competitive advantage. By the same token, the strong influence of non-voluntarism in the study suggests that much of this CSR activity may not be deeply rooted in corporate values and traditions.

These findings have important implications for public policy. In Spain, local and national governments have all gotten involved in CSR activities. The city of Barcelona has its "Proyecte RSC" (CSR Project) based on voluntary measures, although public works projects frequently include CSR measures. The national government passed the "ley de transparencia" (Transparency Law) in December 2003 and has progressively toughened corporate governance and reporting standards for firms that trade on the Madrid Stock Exchange. Various measures to require additional reporting and standards are currently in process in the Spanish legislature. European Union measures affecting principally MNEs remain voluntary. Green papers and communications extolling the virtues of CSR have appeared in 2001, 2002, 2003 and 2006 as pressure from NGOs for binding legislation grows. At this point, the only remaining impediment to new legislation is expressed preference in the European Union for voluntary accords in business regulation.

As governments, the Spanish among them, threaten to pass legislation mandating CSR activity and social and environmental reporting, there is likely to be a further increase in and dependence on non-voluntary obligations. Irrespective of one's view of this type of regulation, it will lead to increased CSR activity. Whether the legislation will encourage firms to seek competitive advantage and value creation via CSR is a separate, though vital question.

Focusing on even just one of the strategy variables...may be

sufficient to create value for the firm

The study has important implications for managers, as well. Clearly, in order to increase value creation from CSR projects, such projects must be designed specifically to accomplish that objective. An essential part of capturing that value is by making sure that such projects are visible. The evidence supports the view that focusing on even just one of the strategy 
variables, in particular visibility, may be sufficient to create value for the firm.

Some caution is warranted. When CSR may be managed for visibility (reputation) in the absence of compliance, the possibilities for "green wash" emerge. The Global Compact itself has become sensitive to charges of "blue wash" as environmentalist and human rights NGOs find MNEs especially adept at putting forward a good looking CSR program while continuing with the same old practices worldwide. In Southern Europe, where it is common to sign accords with high standards but fall short on enforcement, firms seem especially vulnerable to opportunism in relation to CSR. Companies that meet voluntary standards may be those that see a benefit from them, especially in formerly regulated industries and/or consumer goods industries in which product and service differentiation is difficult and reputation with regulators and consumers is a key competitive advantage. Further research into linking regulation, reputation, and CSR behavior is required if we are to understand more fully how companies perceive the competitive advantages available through CSR and what competitive actions they take.

Firm perception of value creation via CSR will also depend on the extent to which managers understand how to integrate CSR into firm business processes; otherwise, CSR will remain for many a necessary, though sometimes uncomfortable appendage whose principal role is to ward off un- pleasant NGOs and potential public relations disasters. Firms which truly integrate CSR into firm market activities, e.g., MRW, remain few. The authors of this article have talked with many in top management responsible for CSR in Spanish MNEs, and most admit privately that they are on shaky ground managing CSR risks and opportunities. Our research confirms this uncertainty and points to the need for additional research on how firms actually manage CSR. Unfortunately, empirical data from independent sources is unreliable and there is almost no case-based research that truly delves into CSR behavior. This is not surprising; few firms are prepared to have their CSR programs evaluated in conjunction with other activities that may not shed a positive light on firm behavior. These limitations must be overcome, so that we can move CSR research forward toward understanding how CSR is integrated into corporate identity and corporate behavior.

This study also makes important contributions to research by providing a basis for operationalizing the strategic dimensions of CSR projects. The Burke and Logsdon model appears to be useful in understanding value creation via CSR projects. Does national context, including laws and culture, affect the strength and direction of the impact of the Burke and Logsdon variables? This test in Spain suggests that other moderating variables must be taken into account. A fundamental objective of future research should be to improve the model and provide managers with better tools for strategic assessment of CSR activities.

We should keep in mind, as well, that Burke and Logsdon's model was one of the first attempts to set out what variables firms ought to manage if they are to achieve strategic success in CSR. This, in itself, was a significant contribution, especially when we consider that at the time, neither researchers nor firms were prepared to consider CSR as a source of competitive advantage. This is consistent with the professional management literature in which influential strategic management models (e.g., Porter's generic strategies) have frequently been proposed without setting out testable propositions, and academics later come forward to test the models.

Accordingly, we ought not to be surprised that the results of our research reconfigure key elements proposed by Burke and Logsdon, demonstrating the extent to which strategic CSR varies from traditional strategy. For example, it appears that firms approach CSR value creation differently from market activities in that visibility (reputation) and making sure that the firm actually benefits (appropriability) are fundamental, rather than the traditional focus on centrality. The negative sign on voluntarism is a further indication that there is significant additional work to be done on strategic CSR, and that firms in Spain are uncertain as to how CSR actually creates value. The Spanish case is important in that Spain is today a strong economy with powerful MNEs that set the agenda for CSR not only in Spain but in much of Latin America. Of course, further research is required in other countries if we are to develop a clearer picture of the key elements involved in CSR value creation and provide managers with strong arguments to move ahead with strategic CSR. 
Appendix 1. Survey questions

Visibility

The purpose of participating in social action programs is to:

- Improve the image of the firm

- Increase the presence of the firm in the media

Appropriability

- The achievement of social objectives is necessary to reach financial

objectives. Voluntarism (note: these items were reverse scaled).

The purpose of participating in social action programs is to:

- Fulfill legal obligations

- Follow a regular practice in the industry

- Obtain favorable tax treatment

Value Creation

- Influence customer purchase decisions

- Obtain new customers

- Develop new products and services

- Open new markets

Appendix 2. Technical material

In order to assess the reliability of the variables developed for this project, Cronbach's alpha was calculated for each variable. Value creation (a $1 / 40.87$ ) was found to have a satisfactory level of re- liability. Visibility (a $1 / 40.68)$ and voluntarism (a 1/4 0.69) were slightly less than the desired level of 0.70 , but sufficient for use in this exploratory kind of research. ${ }^{25}$ Since appropriability was a single-item construct, reliability was not calculated. 26

Construct validity was evaluated by examining the convergent and discriminant validity of the measures. Convergent validity was assessed looking at the pairwise correlations between the items for each construct. All are significant at the $p<0.05$ level, while $94 \%$ are significant at the $p<0.01$ level. Therefore, there is evidence of convergent validity for the different measures.

Discriminant validity is problematic in a survey instrument, which involves self-reports because of problems related to common method variance. In order to diminish these problems, we employed a number of methods. Among others, we avoided implying that one response was preferable to another, made all responses of equal effort, paid attention to item wording, used items that were less subject to bias, and provided clear instructions. ${ }^{27}$

We also carried out a post hoc analysis of the potential problems associated with common method variance using Harman's one-factor test, ${ }^{28}$ which requires the researcher to do a factor analysis of the variables in order to determine if a single factor accounts for the majority of the co- variance in the independent and dependent variables. The variables did not load on a single factor and the most important factor did not account for more than $30.8 \%$ of the variance, suggesting that common method variance was not a significant problem.

In order to test for multicollinearity we examined the variance inflation factor (VIF). VIF is one measure of the effect the other independent variables have on the variance of a regression coefficient. Large VIF values indicate high collinearity. All values of the VIF were below the suggested cutoff of 5.3. ${ }^{29}$ Thus, the problem of multicollinearity does not appear to be significant. The hierarchical regression analysis indicates that the coefficients were generally stable, confirming that multicollinearity did not appear to be affecting the results significantly.

A potential problem that may occur with cross-sectional data is heteroskedasticity, which is a relationship between the error terms over a range of independent variables. In order to test 
for the possibility of heteroskedasticity, we conducted White's test. The test statistic, $\mathrm{nR}^{2}$ was 76.54 , less than the critical Chi-square value. Thus, we satisfy the assumption of homoskedasticity necessary for OLS.

In order to examine non-response bias, we compared the early responders with late responders. This comparison shows no significant difference in firm size, participation in CSR projects, or in competitive environmental factors. In fact, there were no significant differences in the responses to any of the survey questions. Some analysts suggest that late responders are similar to non- responders. ${ }^{30}$ The fact that no significant differences in responses were found between early and late responders suggests that non-response bias is not a problem.

\section{References}

1. A. McWilliams and D. Siegel, Corporate social responsibility: A theory of the firm perspective, Academy of Management Review 26(1), 117e127 (2001) p. 117.

2. Business for Social Responsibility, http://www.bsr.org/Meta/About/index.cfm, Accessed on December 29, 2004; R. M. Kanter, From spare change to real change, Harvard Business Review 77(3), 122e132 (1999); M. E. Porter and R. M. Kramer, The competitive advantage of corporate philanthropy, Harvard Business Review 80(12), 56e68 (2002); United Nations Organization, The Global Compact, http://www.unglobal compact.org, Accessed December 13, 2004.

3. G. Baxter, Speech at Said Business School, Oxford University on December 4, 2006. Accessed at http://www.sbs.ox.ac.uk/news/archives, on January 20, 2007.

4. J. J. Griffin and J. F. Mahon, The corporate social performance and corporate financial performance de- bate: Twenty-five years of incomparable research, Business and Society 36(1), 5e31 (1997); R. M. Roman, S. Heyibor and B. R. Agle, The relationship between social and financial performance, Business and Society 38(1), 109-115 (1999); J. D. Margolis and J. W. Walsh, People and Profits? The Search for a Link between a Firm's Social and Financial Performance, Lawrence Erlbaum Publishers, Mahwah, NJ (2001); A. McWilliams and D. Siegel, Corporate social responsibility and financial performance: Correlation or misspecification? Strategic Management Journal 21, 603-609 (2000); M. O. Orlitzky, F. L. Schmidt and S. L. Rynes, Corporate social and financial performance: A meta-analysis, Organization Studies 24, 403-442 (2003); S. A. Waddock and S. B. Graves, The corporate social performance-financial performance link, Strategic Management Journal 18(4), 303-319 (1997); A. B. Carroll, The pyramid of corporate social responsibility: Toward the moral management of organizational stakeholders, Business Horizons 34(4), 39-48 (1991); D. J. Wood, Corporate social performance revisited, Academy of Management Review 16(4), 691-718 (1991).

5. G. Ray, J. B. Barney and W. D. Muhanna, Capabilities, business processes, and competitive advantage: Choosing the dependent variable in empirical tests of the resource-based view, Strategic Management Journal 25(1), 23-37 (2004).

6. L. Burke and J. M. Logsdon, How corporate social responsibility pays off, Long Range Planning 29,495-502 (1996).

7. D. J. Teece, G. Pisano and A. Shuen, Dynamic capabilities and strategic management, Strategic Manage- ment Journal 18(7), 509-533 (1997); B. Wernerfelt, A resource-based view of the firm, Strategic Manage- ment Journal 5, 171-180 (1984); J. B. Barney, Strategic factor markets: Expectations, luck, and business strategy, Management Science 32(10), 1231-1241 (1986); V. Rindova and C. J. Fombrun, Constructing competitive advantage, Strategic Management Journal 20, 111-127 (1999); M. A. Peteraf, The cornerstones of competitive advantage: A resource-based view, Strategic Management Journal 14, 179-192 (1993).

8. D. Matten and A. Crane, Corporate citizenship: Toward an extended theoretical conception, Academy of Management Review 30(1), 166e179 (2005); A. B. Carroll, The four faces of corporate citizenship, Business and Society Review 100, 1-7 (1998).

9. K. R. Andrews, The Concept of Corporate Strategy (third edition), Dow Jones-Irwin, Homewood, IL (1987); C. Barnard, The Functions of the Executive, Harvard University Press, Cambridge, MA (1938); R. M. Grant, Contemporary Strategy Analysis: Concepts, Techniques, 
Applications, Blackwell Publishers, Oxford (2005).

10. P. Moran and S. Ghoshal, Markets, firms, and the process of economic development, Academy of Management Review 24(3), 390-412 (1999); J. A. Schumpeter, The Theory of Economic Development, Harvard University Press, Cambridge, MA (1934).

11. S. Sharma and H. Vredenburg, Proactive corporate environmental strategy and the development of competitively valuable capabilities, Strategic Management Journal 19, 729-753 (1998).12. A. J. Hillman and G. D. Keim, Shareholder value, stakeholder management, and social issues: What's the bottom line? Strategic Management Journal 22(2), 125-139 (2001).

13. R. Coase, The problem of social cost, Journal of Law and Economics 3, 1-44 (1960).

14. We have done tests that include centrality and proactivity. Although the results for these variables are not significant, the authors would be happy to share these analyses with the interested reader upon request.

15. C. Fombrun and M. Shanley, What's in a name? Reputation building and corporate strategy, Academy of Management Journal 33(2), 233-258 (1990); P. W. Roberts and G. R. Dowling, Corporate reputation and sustained superior financial performance, Strategic Management Journal 23, 1077-1093 (2002).

16. J. Shamsie, The context of dominance: An industry-driven framework for exploiting reputation, Strategic Management Journal 24(3), 199-215 (2003); D. Deephouse, Media reputation as a strategic resource: An integration of mass communication and resourcebased theories, Journal of Management 26(6), 1091-1112 (2000); J. B. Barney, Firm resources and sustained competitive advantage, Journal of Management 17, 99-120 (1991).

17. S. Yost, Corporate Counsel, Neopets, Personal communication with the authors (2005).

18. D. Allen and R. Eguía, Telefonica Reputation Project "A", Instituto de Empresa, Madrid, Spain (2004).

19. F. Reinhardt, Market failure and the environmental policies of firms: Economic rationales for "beyond compliance" behavior, Journal of Industrial Ecology 3(1), 9-21 (1999).

20. D. Baron, Integrated strategy: Market and non-market components, California Management Review 32(2), 47-65 (1995).

21. I. Dierickx and K. Cool, Asset stock accumulation and sustainability of competitive advantage, Manage- ment Science 35(12), 1504-1513 (1989).

22. M. E. Porter and C. van der Linde, Toward a new conception of the environmentcompetitiveness relationship, Journal of Economic Perspectives 9(4), 97 e118 (1995); S. Managi, J. J. Opaluch, D. Jin and T. A. Grigalunas, Environmental regulations and technological change in the offshore oil and gas industry, Land Economics 81(2), 303-319 (2005).

23. P. R. Lawrence and J. W. Lorsch, Organization and Environment: Managing Differentiation and Integration, Graduate school of Business Administration, Harvard University, Boston, MA (1967); B. K. Boyd, G. G. Dess and A. M. A. Rasheed, Divergence between archival and perceptual measures of the environment: Causes and consequences, Academy of Management Review 18(2), 204-226 (1993).

24. Anonymous, The good company, The Economist 374(8410), 11 (2005).

25. J. C. Nunnally and I. H. Bernstein, Psychometric Theory (third edition), McGraw-Hill, New York (1994).

26. G. Gardner, L. L. Cummings, R. B. Dunham and J. L. Pierce, Single-item versus multipleitem measurement scales: An empirical comparison, Educational and Psychological Measurement 58(6), 898-915 (1998).

27. J. C. Nunnally and I. H. Bernstein (op. cit. at Ref 25), p. 391.

28. P. M. Podsakoff and D. W. Organ, Self-reports in organizational research: Problems and prospects, Journal of Management 12, 531-544 (1986).

29. J. F. Hair, R. E. Anderson, R. L. Tatham and W. C. Black, Multivariate Data Analysis, Macmillan, New York (1992).

30. J. S. Armstrong and T. S. Overton, Estimating nonresponse bias in mail surveys, Journal of Marketing Research 18(3), 396-402 (1977). 